\title{
UNIDROIT 1995:Tackling the illicit trafficking of cultural property through private law means
}

Citation for published version (APA):

Groenen, A. C. C. (2018). UNIDROIT 1995:Tackling the illicit trafficking of cultural property through private law means: An evaluation of the appropriateness of the 1995 Unidroit Convention on Stolen or Illegally Exported Cultural Objects to Cultural Property Theft in comparative perspective . [Doctoral Thesis, Maastricht University, tUL-Universiteit Hasselt (UHasselt)]. Datawyse / Universitaire Pers Maastricht. https://doi.org/10.26481/dis.20181002ag

Document status and date:

Published: 01/01/2018

DOI:

10.26481/dis.20181002ag

Document Version:

Publisher's PDF, also known as Version of record

\section{Please check the document version of this publication:}

- A submitted manuscript is the version of the article upon submission and before peer-review. There can be important differences between the submitted version and the official published version of record.

People interested in the research are advised to contact the author for the final version of the publication, or visit the DOI to the publisher's website.

- The final author version and the galley proof are versions of the publication after peer review.

- The final published version features the final layout of the paper including the volume, issue and page numbers.

Link to publication

\footnotetext{
General rights rights.

- You may freely distribute the URL identifying the publication in the public portal. please follow below link for the End User Agreement:

www.umlib.nl/taverne-license

Take down policy

If you believe that this document breaches copyright please contact us at:

repository@maastrichtuniversity.nl

providing details and we will investigate your claim.
}

Copyright and moral rights for the publications made accessible in the public portal are retained by the authors and/or other copyright owners and it is a condition of accessing publications that users recognise and abide by the legal requirements associated with these

- Users may download and print one copy of any publication from the public portal for the purpose of private study or research.

- You may not further distribute the material or use it for any profit-making activity or commercial gain

If the publication is distributed under the terms of Article $25 \mathrm{fa}$ of the Dutch Copyright Act, indicated by the "Taverne" license above, 
Praised by some writers as an appropriate instrument to tackle the illicit trafficking of cultural property and criticized by other commentators as a stillborn project, the 1995 UNIDROIT Convention on Stolen or Illegally Exported Cultural Objects has, since its adoption, been - and still is - much debated. In an attempt to clarify the on-going debate, the present study posits three key questions: what merits of Chapter II of the 1995 UNIDROIT convention contribute to the achievement of its objective of becoming an appropriate tool against cultural property theft? What pitfalls of the convention thwart it in the said enterprise? And, finally, how can the scrutinised regime be improved to foster adherence to the convention? To answer these questions, this contribution investigates the inner workings of this instrument in addressing cultural property theft and the plunder of archaeological materials.

In doing so, the research firstly presents the convention in its context, discusses the preparatory work towards its adoption, assesses its objectives and sketches out its structure. It finds, inter alia, that the 1995 UNIDROIT convention is the successor to the 1970 UNESCO convention in fighting the illicit trafficking of cultural property in times of peace and constitutes a private law complement to Article 7 (b) (ii) of the latter. Furthermore, it unveils that the 1995 convention is set to regulate the demand side of the art and antiquities markets by addressing the scenario of good faith acquisitions of cultural objects. As such, the treaty attempts to alter the practices of market stakeholders and to create a gradual change of mentality by making the sale of cultural objects of dubious origins more difficult.

Secondly, the study delimits the convention's scope of application and, thus, analyses the instances within which its regime applies. It determines that the treaty is exclusively concerned with claims for the restitution and the return of stolen or illegally exported cultural objects that have crossed a border. What is more, it establishes that the convention is not retroactive and only applies to acts that have taken place after 1 July 1998. Importantly, the research clarifies the implications of Article 10, which explains more specifically when the theft or illegal export must have taken place to fall within the convention's ambit.

Thirdly, the dissertation analyses the applicable rules on restitution and third-party protection in six different states: Belgium, France, The Netherlands, New Jersey, California and New York. In the first place, it introduces the basic concepts and principles that underlie these rules. Subsequently, it operationalises these concepts and principles by explaining how the restitutionary and third-party protection rules operate. Finally, it considers the legal implications flowing from those rules.

Fourthly, the restitutionary regime for stolen cultural objects laid down in Chapter II of the convention is elucidated. A sequential order is given by which the prerequisites for lodging a claim in restitution, the timeliness of the claim, the rules on restitution, as well as the entitlement to and amount of fair and reasonable compensation are discussed. To further explain these rules, the findings of the comparative analysis of the afore-mentioned jurisdictions are extrapolated to the regime of Chapter II. The main observations distilled from this exercise are that:

A. Chapter II mandates the automatic return of a stolen cultural object when a claim in restitution is timely introduced. In accordance with the six jurisdictions discussed, the convention abides by the nemo dat quod non habet principle by mandating the restitution of a stolen cultural object. Nevertheless, much like New Jersey, California and New York law, the convention subjects a claim for the restitution to specific time restrictions. Therefore, Article 3 (3) requires a claim to be brought in accordance with a relative and an absolute period. The relative period is construed in accordance with the discovery rule as laid down in New Jersey and California law. Furthermore, the absolute period of fifty years makes it impossible to bring a claim for restitution more than fifty years after the theft took place. 
B. Next to the regime of Article 3 (3), the research addresses the exceptions applicable for cultural objects embedded with a certain importance to the cultural heritage of contracting states: Article 3 (4) and (5) provide two exceptions applicable to cultural objects forming an integral part of an identified monument, of an identified archaeological site or stemming from a public collection, as described in Article 3 (4)-(8). Sacred or communally important cultural objects belonging to and used by a tribal or indigenous communities in a contracting state as part of that community's traditional or ritual use are subjected to the same rules as the ones applicable to public collections.

C. The study further found that the legal effect flowing from the expiration of both the relative and absolute periods remain unclear. As the relative period was inspired by the New Jersey and California Discovery Rule, its expiration ought to be embedded with similar traits. Nonetheless, both jurisdictions differ in the legal effect flowing from this expiration, as the New Jersey approach operates upon the right and the Californian approach affects the remedy. With regard to the expiration of the absolute period, it is unquestionable that the owner loses his right of ownership and that the possessor becomes the owner of the stolen property.

D. Provided the claim is timely introduced, the merits of the case are dealt with by Articles 3 (1) and 4 of the convention. Article 3 (1) prescribes the unconditional return of a stolen cultural object. Article 4 (1) entitles an acquirer as of right to receive fair and reasonable compensation, subject to specific conditions. Compensation is not automatic, but will only have to be paid when this possessor did not know, nor ought to have known, during the acquisition that the cultural object was stolen, and can prove that he exercised due diligence at the time of the acquisition (as defined in Article 4 (4)). Put differently, the possessor must prove that he acquired the cultural object in good faith. The protection of good faith acquirers is a main tenet of the rules on third-party protection found in Belgian, French and Dutch law. Therefore, good faith for the purpose of the convention is compared with domestic articulations of this notion. Nevertheless, unlike the three jurisdictions just referred to, good faith is not presumed by the convention. Hence, the burden of proof is shifted to the possessor by requiring him to demonstrate his good faith through the exercise of due diligence.

E. Although Article 4 primarily targets acquisitions for value, gratuitous acquisitions are also incorporated within the regime of Chapter II, ensuring that cultural objects cannot be laundered through means of donation or bequeathals.

F. By obliging the possessor of a stolen cultural object to return it and lose the right to fair and reasonable compensation when he was not sufficiently diligent during the acquisition, it is assumed that this will give the acquirer sufficient incentive to be cautious throughout the acquisition. Subsequently, this will lead to a diminution of transactions involving cultural objects with a dubious origin, tackling the secrecy and connivance of the art market and deterring cultural property theft in the long run. Therefore, the research finds that both Articles 3 (1) and 4 (1) are key to the fight against the illicit traffic in stolen cultural property.

G. To set the amount of fair and reasonable compensation, the research establishes that account may be taken of a panoply of facts, including for example: the market value of the object; the price paid; the financial resources of the claimant; the amount that the possessor is willing to accept as compensation; the solvability of the claimant; the possibility for the purchaser to recover money from the seller; etc. The study also lists the elements that ought not to be computed in the fair and reasonable compensation and further discusses some limitations to the interpretation of this notion. Finally, attention is devoted to the modalities of payment.

Fifthly, the manuscript discusses the causes and effects of archaeological theft as well as the response of source states in dealing with this problem and elaborates on the solutions instated by the UNIDROIT 
convention. It establishes that the convention prescribes for the return of a cultural object, respectively in Chapters II (cf. Article 3 (2)) and III (cf. Article 5 (3)). As such, it finds that the Model Provisions on State Ownership of Undiscovered Cultural Objects is well suited to assist contracting states in benefiting from Article 3 (2) to its fullest. Moreover, although the drafters have not foreseen of a hierarchy between Chapters II and III of the convention, the research observes that Article 5 (3) constitutes a safety net for contracting states that encounter difficulties in reclaiming the artefact on the basis of Article 3 (2).

Sixthly, the dissertation addresses matters relating to the application of the instated regime such as reservations; the convention's self-executing nature; the adoption of rules more favourable to restitution and / or return; and the interpretation of the convention. Additionally, it touches upon the means of monitoring the convention's application. With regard to the rules more favourable to restitution or return, the research finds that Article 9 (1) makes it possible for contracting states to modify the regime of the convention in many ways. It is thus possible to apply the convention to claims of a purely national character; to retract the payment of compensation to an acquirer in good faith (only when the domestic law of the contracting state already foresees that no compensation is to be paid); to extend the period of time for recovering the stolen property; to adopt longer periods for introducing the demand in return; etc. Additionally, it is possible for a contracting state to extend the temporal scope of the convention by applying it to thefts or illegal exports that have taken place before the adoption of, or the adhesion to, the convention. Nevertheless, the research further explains how Article 9 (2) limits the legal effect of the choice operated.

Seventhly, this work positions the convention in the existing international legal framework: the interaction of the convention with other international norms, as regulated by Article 13 (1), is discussed in detail in relation the 1970 UNESCO convention. What is more, the possibility for contracting parties to adopt agreements in order to improve the application of the convention in their mutual relations (Article 13 (2)) is also considered. Additionally, the relative system instated by Article 13 (3), which enables members of economic integration organisations or regional bodies to apply internal rules in their mutual relations, is scrutinised. For the purpose of the research, this scheme is studied in the context of the relationship between the UNIDROIT convention and both former Directive 93/7/EEC and its recast, Directive 2014/60/EU.

Finally, the research concludes that the regime of restitution laid down in Chapter II is appropriate to tackling both cultural property theft and archaeological theft. More specifically, it observes that the regime is conducive to moralising the art market and to rendering cultural objects of dubious origins unmarketable. As such, it appropriately tackles the secrecy and connivance that often characterizes the art market. Furthermore, the compromise achieved within the convention is deemed well balanced as this instrument borrows the restitutionary rules of New Jersey and California in combination with rules on third party protection, in accordance with Belgian, French and Dutch law. It also finds that any potential drawbacks encountered in the studied regime cannot outweigh the advantages brought by the convention. Instead, it opines that further fine-tuning by UNIDROIT or its 1995 UNIDROIT Convention Academic Project (UCAP) could help alleviate certain concerns raised about the convention. The research concludes by formulating recommendations for the consideration of both UNIDROIT and the UCAP. 

Het UNIDROIT-Verdrag van 1995 inzake gestolen of illegaal uitgevoerde cultuurgoederen wordt door sommige schrijvers geprezen als een geschikt instrument om de illegale handel in cultuurgoederen aan te pakken, maar wordt door andere commentatoren als een doodgeboren project bekritiseerd. In een poging het lopende debat te verhelderen, worden in deze studie drie belangrijke vragen gesteld: Welke verdiensten van hoofdstuk II van het UNIDROIT-verdrag van 1995 dragen bij aan het bereiken van de doelstelling van het verdrag om een geschikt instrument tegen diefstal van cultureel eigendom te worden? Welke valkuilen van de conventie dwarsbomen deze onderneming? En ten slotte, hoe kan dit stelsel worden verbeterd om toetreding tot het verdrag te bevorderen? Om deze vragen te beantwoorden, onderzoekt dit proefschrift de werking van dit instrument in de strijd tegen de diefstal van cultureel eigendom en de plundering van archeologische objecten.

In dit onderzoek wordt allereerst het verdrag besproken door het te contextualiseren, de voorbereidende werken te bediscussiëren, de nagestreefde doelstellingen te beoordelen en de structuur ervan te schetsen. Het onderzoek stelt onder meer vast dat het UNIDROIT-verdrag van 1995 de opvolger is van het UNESCO-verdrag van 1970 ter bestrijding van de illegale handel in culturele goederen in vredestijd en dat het een privaatrechtelijke aanvulling vormt op Artikel 7 onder b) ii) van dit laatste instrument. Voorts wordt aangetoond dat het verdrag van 1995 de vraagzijde van de kunst- en antiekmarkt reguleert: Dit door de praktijk van het te goeder trouw verwerven van cultuurgoederen te herzien. Het verdrag probeert de handelwijze van marktpartijen te veranderen en een geleidelijke mentaliteitsverandering te bewerkstelligen door de verkoop van cultuurgoederen van dubieuze herkomst te bemoeilijken.

Ten tweede wordt in dit proefschrift het toepassingsgebied van het verdrag afgebakend en worden meerdere gevallen geanalyseerd waarbij het stelsel van toepassing is. Het verdrag heeft uitsluitend betrekking op vorderingen tot teruggave van gestolen cultuurgoederen en teruggave van gestolen of illegaal uitgevoerde cultuurgoederen die een grens gepasseerd zijn. Bovendien wordt bepaald dat het verdrag geen terugwerkende kracht heeft en van toepassing is op tansacties die plaatsvinden na 1 juli 1998. Belangrijk is dat het onderzoek de implicaties van Artikel 10 verduidelijkt, waarbij specifiek wordt uitgelegd wanneer en waar de diefstal of illegale uitvoer moet hebben plaatsgevonden om binnen de werkingssfeer van het verdrag te vallen.

Ten derde wordt in het onderzoek een analyse gemaakt van het restitutiestelsel en de regels inzake de bescherming van derden welke in zes verschillende staten van toepassing zijn: België, Frankrijk, Nederland, New Jersey, Californië en New York. In eerste instantie worden de basisbegrippen en beginselen die aan de beoogde regels ten grondslag liggen geïntroduceerd. Vervolgens operationaliseert het deze begrippen door uit te leggen hoe de regels die betrekking hebben op restitutie en de derdenbescherming functioneren. Tot slot wordt ingegaan op de juridische gevolgen van deze regels.

Ten vierde wordt het in Hoofdstuk II van het verdrag besproken restitutiestelsel voor gestolen cultuurgoederen toegelicht. Er wordt een volgorde gegeven waarin de voorwaarden voor het indienen van een vordering tot teruggave, de tijdigheid van de vordering, de regels inzake teruggave, alsmede het recht op en de hoogte van een billijke en redelijke vergoeding worden besproken. Om deze regels verder toe te lichten, worden de bevindingen van de vergelijkende analyse van eerdergenoemde jurisdicties geëxtrapoleerd naar het stelsel van Hoofdstuk II. De belangrijkste opmerkingen die uit deze vergelijking zijn gedistilleerd zijn als volgt:

A. Hoofdstuk II schrijft in alle gevallen de teruggave van een gestolen cultuurgoed voor wanneer een vordering tot teruggave tijdig wordt ingediend. In overeenstemming met de zes besproken jurisdicties houdt het verdrag zich aan het nemo dat quod non babet beginsel door de teruggave van een gestolen cultuurgoed verplicht te stellen. Echter, het verdrag stelt een vordering tot teruggave in die, net als de wet van New Jersey, Californië en New York, afhangt van specifieke tijdsbeperkingen. Artikel 3, lid 3, schrijft derhalve voor dat een vordering moet worden ingesteld in overeenstemming met zowel een relatieve als een absolute termijn. De relatieve periode wordt geïnterpreteerd in overeenstemming met de ontdekkingsregel zoals vastgelegd in de wet van New Jersey en Californië. Bovendien is het door de absolute termijn van vijftig jaar onmogelijk om meer dan vijftig jaar na de diefstal een vordering tot teruggave in te stellen. 
B. Naast het regime van Artikel 3, lid 3, richt het onderzoek zich ook op de uitzonderingen die van toepassing zijn op cultuurgoederen die van belang zijn voor het cultureel erfgoed van verdragsluitende staten: Artikel 3, leden 4 en 5, voorziet in twee uitzonderingen die van toepassing zijn op cultuurgoederen die integraal deel uitmaken van een geïdentificeerd monument, van een geïdentificeerde archeologische site of afkomstig zijn uit een openbare collectie, zoals beschreven in Artikel 3, leden 4 tot en met 8 . Voor heilige of gemeenschappelijk belangrijke cultuurgoederen die toebehoren aan en gebruikt worden door stammen of inheemse gemeenschappen in een verdragsluitende staat in het kader van het traditionele of rituele gebruik van die gemeenschap gelden dezelfde regels als die welke van toepassing zijn op openbare collecties.

C. Verder wordt in de studie vastgesteld dat het rechtsgevolg van het verstrijken van zowel de relatieve als de absolute periode onduidelijk blijft. Aangezien de relatieve periode werd gebaseerd op de discovery rule van New Jersey en Californië, zou het verstrijken van deze periode vergelijkbare eigenschappen moeten omvatten. Niettemin verschillen beide jurisdicties van elkaar inzake het rechtseffect van dit verval, aangezien de New Jersey-benadering op dit recht inwerkt en de Californische benadering het rechtsmiddel beïnvloedt. Wat het verstrijken van de absolute termijn betreft, is het vrijwel zeker dat de eigenaar zijn eigendomsrecht verliest en dat de bezitter eigenaar wordt van het gestolen goed.

D. Mits de vordering tijdig wordt ingesteld, wordt de grond van de zaak behandeld in Artikel 3, lid 1, en Artikel 4 van het verdrag. Artikel 3, lid 1, schrijft de unconditional return van een gestolen cultuurgoed voor. Artikel 4, lid 1, geeft een acquirer as of right onder specifieke voorwaarden recht op een billijke en redelijke vergoeding. Deze vergoeding is niet vanzelfsprekend, maar hoeft alleen te worden betaald wanneer de bezitter tijdens de verkrijging niet wist of had moeten weten dat het cultuurgoed was gestolen, en kan aantonen dat hij op het moment van de verkrijging de nodige zorgvuldigheid in acht had genomen (zoals gedefinieerd in Artikel 4, lid 4). Anders gezegd, de bezitter moet bewijzen dat hij het cultuurgoed te goeder trouw heeft verworven. De bescherming van verkrijgers die te goeder trouw zijn, is een basisbeginsel van de regels inzake de bescherming van derden in het Belgische, Franse en Nederlandse recht. Daarom wordt goede trouw, zoals besproken in het verdrag, vergeleken met binnenlandse verwoordingen van dit begrip. In tegenstelling tot de drie bovengenoemde jurisdicties, wordt goede trouw door het verdrag niet verondersteld. De bewijslast ligt dus bij de bezitter door hem te verplichten de nodige zorgvuldigheid toe te passen bij het bewijzen van zijn goede trouw.

E. Hoewel Artikel 4 in de eerste plaats betrekking heeft op verkrijgingen van waarde, zijn verkrijgingen om niets ook in hoofdstuk II van het verdrag opgenomen, zodat cultuurgoederen niet via schenking of nalatenschap kunnen worden witgewassen.

F. Door de bezitter van een gestolen cultuurgoed te verplichten tot teruggave en het recht op een billijke en redelijke vergoeding te ontnemen wanneer hij tijdens de verwerving niet de noodzakelijke zorgvuldigheid toepast, wordt ervan uit gegaan dat dit de verkrijger voldoende zal stimuleren om gedurende de verwerving voorzichtig te zijn. Dit zal niet alleen leiden tot een vermindering van transacties die betrekking hebben op cultuurgoederen van twijfelachtige herkomst, maar ook de geheimhouding en het stilzwijgend medeweten van de kunstmarkt aanpakken en de diefstal van cultuurgoederen ontmoedigen. Uit het onderzoek blijkt dan ook dat zowel Artikel 3, lid 1, als Artikel 4, lid 1, van essentieel belang zijn voor de bestrijding van de illegale handel in gestolen cultuurgoederen.

G. Om het bedrag van de billijke en redelijke vergoeding vast te stellen, blijkt uit het onderzoek dat rekening kan worden gehouden met een hele reeks feiten, waaronder bijvoorbeeld: De marktwaarde van het object; de prijs die werd betaald; de financiële middelen van de eiser; het bedrag dat de bezitter bereid is als vergoeding te aanvaarden; de solvabiliteit van de eiser; de mogelijkheid voor de koper om geld bij de verkoper te verhalen, enz. Ook geeft de studie een opsomming van de elementen die niet mogen worden meegewogen in de berekening van de billijke en redelijke vergoeding. Verder bespreekt het enkele beperkingen die aan de interpretatie van dit begrip gebonden zijn. Ten slotte wordt aandacht besteed aan alle aspecten die betrekking hebben op de betaling.

Ten vijfde gaat de studie in op de oorzaken en gevolgen van archeologische diefstal; de respons van bronstaten bij de annpak van dit probleem; en bespreekt het de oplossingen die het UNIDROIT-verdrag biedt. Het onderzoek bevestigt dat het verdrag de teruggave voorschrijft van een cultuurgoed welke uit archeologische diefstal voortvloeit. Dit wordt besproken in hoofdstuk II (zie Artikel 3, lid 2) en hoofdstuk III (zie Artikel 5, lid 
3). Uit het onderzoek blijkt dan ook dat de Model Provisions on State Ownership of Undiscovered Cultural Objects zeer geschikt zijn om verdragsluitende staten te ondersteunen in de toepassing van Artikel 3, lid 2. Hoewel de opstellers van het verdrag hoofdstuk II en hoofdstuk III niet van een hiërarchie hebben voorzien, wordt in het onderzoek opgemerkt dat Artikel 5, lid 3, een vangnet vormt voor verdragsluitende staten die moeilijkheden ondervinden bij het terughalen van een artefact op basis van Artikel 3, lid 2.

Ten zesde gaat het proefschrift in op zaken die te maken hebben met de toepassing van het verdrag, zoals voorbehouden; de rechtstreekse werking van het verdrag; het vaststellen van regels die gunstiger zijn voor restitutie en/of terugkeer en de interpretatie van het verdrag. Daarnaast worden de toezichtsmiddelen van het verdrag besproken. Wat betreft de regels die gunstiger zijn voor teruggave of terugkeer, is uit het onderzoek gebleken dat Artikel 9, lid 1, de verdragsluitende staten in staat stelt de regeling van het verdrag op vele manieren te wijzigen. Zo is het mogelijk het verdrag toe te passen op vorderingen van louter nationale aard; de betaling van schadevergoeding aan een te goeder trouw wervende koper in te trekken (alleen wanneer het nationale recht van het verdragsland reeds bepaalt dat geen schadevergoeding hoeft te worden betaald); de termijn voor het terugeisen van de gestolen goederen te verlengen; langere termijnen vast te stellen voor het indienen van het verzoek tot teruggave; enz. Bovendien kan een verdragsluitende staat het toepassingsgebied van het verdrag verlengen door het toe te passen op diefstallen of illegale uitvoer die vóór de inwerkingstreding van of de toetreding tot het verdrag hebben plaatsgevonden. Niettemin wordt in het onderzoek nader toegelicht hoe Artikel 9, lid 2, de rechtsgevolgen van de gemaakte keuze beperkt.

Ten zevende plaatst dit werk het verdrag in het bestaande internationale juridische kader: De interactie van het UNIDROIT-verdrag met andere internationale normen (zoals geregeld in Artikel 13, lid 1) wordt in detail besproken in relatie tot het UNESCO-verdrag van 1970. Verder wordt de mogelijkheid voor verdragsluitende partijen bestudeerd om overeenkomsten te sluiten voor het bevorderen van de toepassing van het verdrag in hun onderlinge betrekkingen (Artikel 13, lid 2). Zo ook wordt het door Artikel 13, lid 3, ingevoerde relatieve mechanisme, dat leden van organisaties voor economische integratie of regionale organen in staat stelt in hun onderlinge betrekkingen interne regels toe te passen, onder de loep genomen. In het kader van het onderzoek wordt deze regeling bestudeerd in de context van de relatie tussen het UNIDROIT-verdrag en zowel de vroegere Richtlijn 93/7/EEG als de herschikking ervan, Richtlijn 2014/60/EU.

Tot slot concludeert het onderzoek dat de restitutieregeling van hoofdstuk II geschikt is om zowel diefstal van cultuurgoederen als archeologische diefstal aan te pakken. Meer specifiek merkt het op dat het regime bijdraagt aan het moraliseren van de kunstmarkt en het ontmaskeren van cultuurgoederen van dubieuze herkomst. Zo pakt het op gepaste wijze de geheimzinnigheid en het stilzwijgend medeweten aan die vaak typerend zijn voor de kunstmarkt. Bovendien wordt het binnen het verdrag bereikte compromis evenwichtig bevonden, aangezien het verdrag is ontleend aan de restitutieregels van New Jersey en Californië en deze combineert met de regels inzake de bescherming van derden, overeenkomstig met de Belgische, Franse en Nederlandse wetgeving. Tevens concludeert het onderzoek dat de eventuele nadelen niet opwegen tegen de voordelen van het verdrag. In plaats daarvan betoogt het proefschrift dat een aantal verfijningen door UNIDROIT of het 1995 UNIDROIT Convention Academic Project (UCAP) aan het verdrag dienen te worden aangebracht, omdat dit bepaalde bezwaren tegen het verdrag zou kunnen wegnemen. Het onderzoek sluit af met het formuleren van aanbevelingen ter overweging van zowel UNIDROIT als de UCAP. 